Jurnal Ilmiah Al-Syir'ah Vol. 18, No. 1 (2020): 50-62

Website: http://journal.iain-manado.ac.id/index.php/JIS

ISSN 2528-0368 (online) ISSN 1693-4202 (print)

\title{
TALAQQI RUKBAN AND IHTIKAR IN THE TRADITIONAL MARKET AT MAKASSAR IN PERSPECTIVE OF ISLAMIC ECONOMIC LAWS
}

\author{
Nurnaningsih Nawawi \\ Faculty of Sharia, Universitas Islam Negeri Alauddin Makassar, \\ J1. Sultan AlauddinNo. 63, Romangpolong, Somba Opu, Kec. Somba Opu, \\ Kabupaten Gowa, Sulawesi Selatan, Indonesia, 92113 \\ E-mail: nurnaningsih.masnaw @uin-alauddin.ac.id
}

\begin{abstract}
This article discusses talaqqi rukban, a buying and selling tactic that seen as violating Islamic Economic Law. Where this practice is detrimental to sellers who sell their agricultural products because they are hindered by unscrupulous buyers who offer the prices of such farm products at prices far below the actual market price. This trading system, of course, is a fraud because the seller of agricultural products does not know the actual price and suffers from it. There are also sellers in the market monopolize certain goods in the market so that the costs of these goods rise dramatically. Sellers who carry out the monopoly get big profits while the people who become consumers are disadvantaged. This practice in Islam is called Ihtikar. This research uses descriptive qualitative research methods with a normative sociologies approach. In Islamic Economic Law, this practice strictly prohibited. It is a prohibited sale and purchase, but in Makassar, the practice of Talaqqi Rukban and Ihtikar still often occurs, whereas when viewed from the background of the Talaqqi Rukban and Ihtikar perpetrators are religious people. Of course, the practice is following Islamic Economic Law based on the Qur'an and Hadith. This research will propose a system, form, and analysis of some views of Jumhur scholars about the law, the terms of sale and purchase, which are: forbidden, obligatory, Sunnah, and makruh following Islamic economic law.
\end{abstract}

Keywords: Talaqqi Rukban; Ihtikar; Islamic Economic Law; Market.

How to Cite: Nawawi, N. (2020). Talaqqi Rukban and Ihtikar in The Traditional Market at Makassar in Perspective of Islamic Economic Laws. Jurnal Ilmiah Al-Syir'ah, 18(1), 50-62.

Permalink/DOI: http://dx.doi.org/10.30984/jis.v18i1.1074

Copyright (C) 2020, Jurnal Ilmiah Al-Syir'ah 


\section{Jurnal Ilmiah Al-Syir'ah Vol. 18, No. 1 (2020): 50-62 \\ Website: http://journal.iain-manado.ac.id/index.php/JIS \\ ISSN 2528-0368 (online) ISSN 1693-4202 (print)}

\section{INTRODUCTION}

Trade is a form of business that mostly done in the community, both individual companies, and legal entities, on a small scale and large scale. In this trading business, of course, there are prohibited trading. The banned trading system is known as fiqh, including Talaqqi Rukban and Ihtikar.

Talaqqi Rukban which is often also referred to as talaqqi as-silai is terminology in muamalah fiqh which describes a process of buying and selling goods/commodities by intercepting or blocking the villagers (caravans). Who carry their merchandise which are agricultural products, such as rice, corn sugar, and other agrarian ingredients before reaching the market to be able to buy goods below the prevailing market price. This practice can bring losses to villagers who do not know/are blind / at prices that are prevailing in the market (Asyari, 2003).

The author can conclude that Talaqqi Rukban is an event where a buyer intercepts a merchandise group before entering the market. In this case, buying and selling are carried out by prospective sellers who will initially sell their merchandise in the market but do not yet know the standard market prices. The behavior of the buyers intentionally intercepts the seller to play with the cost of the merchandise. Then this method is not allowed because it is a form of fraud.

In the life of modern society, the Talaqqi Rukban sale and purchase transaction has become an entrenched trend that has penetrated in various segments of society's life, especially when looking at the consumptive lifestyle that is increasingly widespread in people's lives. Become one of the habits of the people in buying and selling to intercept or deception as an effort to seek unilateral profits, without any sense of human considerations that contain sins that this behavior generally played by people who have Muslim ID cards.

The sale and purchase of talaqqin rukban are prohibited because there is an element of injustice to the actions taken by traders in the city who do not provide information to sellers from rural areas regarding the actual prices prevailing in the market. In a buying and selling system, one of the essential things in a transaction is the issue of cost, where the selling price, according to economic theory, is based on the base price plus the agreed profit (Mankiw, 2013).

There is also a trading system in the form of ikhtikar, which is also called the hoarding of commodity, which is one of the economic problems that are quite serious, except that Islam has normatively predicted it. This trading system can trace through the understanding of the Qur'an in the QS. Yusuf verses 43-48, which shows how the Prophet Joseph was very concerned about what would happen to the Egyptians, so he encouraged them to plant wheat and set aside a large portion of it to become a national food reserve. The action was very appropriate for the Prophet Yusuf so that the consequences of famine would avoid but there was a perception

Talaqqi Rukban and Ihtikar in The Traditional Market at Makassar in Perspective of Islamic Economic Laws Nurnaningsih Nawawi 


\section{Jurnal Ilmiah Al-Syir'ah Vol. 18, No. 1 (2020): 50-62 \\ Website: http://journal.iain-manado.ac.id/index.php/JIS \\ ISSN 2528-0368 (online) ISSN 1693-4202 (print)}

that, on the other hand, it seen as Ihtikar according to the understanding of some of the hadiths, in general, giving negative justification to the practice of Ihtikar. From this, it can understand that the perpetrators of Ihtikar (muttakir) sinning about his actions could cause difficulties for the community in terms of getting their needs.

There are several studies related to Talaqqi Rukban and Ihtikar. Still, there is no specific research that examines both, namely: (1) Research conducted by Sri Mentari (2015) where the study only focuses on the transaction process or aqad sale and purchase of Talaqqi Rukban, contracts and perspectives Islamic law; (2) Arief Himawan (2011) which highlights activities that clash with Sharia principles including usury, bai 'al-ma'dum, talaqqi rukban, tadlis, gharar, ihtikar and bai' najsy; (3) Anik Fitriyah Ulfah (2010) who conducted a literature review on the background of al-Ghazali's thoughts on ihtikar (stockpiling of goods); (4) Moch. Bukhori Muslim (2010), who writes about the impact of ihtikar on the world economy; (5) Siti Baliza Binti Marukum (2012) also conducted a literature review on Yusuf Qardhawi's thoughts on ihtikar from an Islamic economic perspective; (6) Darnela Putri (2019) who traces the impact of ihtikar on market mechanisms in Islamic perspective. These studies do not discuss Talaqqi Rukban and Ihtikar individually. In contrast, the article wrote by Arief Hermawan only talks in general about economic activity in this case, public buying, and selling.

The Talaqqi Rukban and Ihtikar trading systems are often also in the traditional markets of Makassar city, although it can happen in other cities. It generally occurs in the sale of basic foodstuffs such as rice, corn, and other food servants. It can also be found in sales goods such as fruits and vegetables side dishes and spices because these commodities generally carried by sellers who come from rural areas. Such as districts: Gowa, Takalar, Jeneponto to Selayar Island to the south, as well as from northern communities from Maros, Tanah Toraja, and Luwu Palopo.

So far, the author has not found a specific study that examines Talaqqi Rukban and Ihtikar even though, when viewed from the practical side, the two practices are interrelated, the aim is the same. To get the maximum profit from the buyers, but spend the smallest capital. But on the other hand, both of these practices harm the wider community.

Perpetrators of buying and selling practices are generally dominated by people who are known as religious pilgrims and often interact with the community. Interaction with the community is usually carried out around the mosque because the traditional market in Makassar is on the edge of the highway. And almost all of them are adjacent to the mosque - for example, Pasar Terong, which is the location at Jln. Mesjid Raya is facing the al-Headquarters of Al-Islami Mosque, which is a minimum of two prayer times after completion (evening and even Duhur always filled with religious studies but buying and selling treatment which is categorized as prohibited is still often found. This situation is of concern to the author. It is interested in conducting research related to the Talaqqi Rukban and Ihtikar trading system in Makassar. In conducting studies so that these practices can be overcome

Talaqqi Rukban and Ihtikar in The Traditional Market at Makassar in Perspective of Islamic Economic Laws 


\section{Jurnal Ilmiah Al-Syir'ah Vol. 18, No. 1 (2020): 50-62 \\ Website: http://journal.iain-manado.ac.id/index.php/JIS \\ ISSN 2528-0368 (online) ISSN 1693-4202 (print)}

properly so that people can be enlightened and educate the public so they can avoid the practice of Talaqqi Rukban and Ihtikar.

\section{RESEARCH METHODS}

This research uses descriptive qualitative research methodology, qualitative. In contrast, the approach used is a sociological and normative approach by conducting data collection techniques through (Daymon \& Holloway, 2008): (1) Observation of the market environment/sales centers in traditional markets in Makassar through several samples that were targeted by the study; (2) FGD on five people (two sellers and three buyers) who were directly involved with the Talaqqi Rukban practice on Monday, December 2, 2019, at the al-Headquarters Al-Islami Mosque; (3) Interviews with informants were conducted based on their knowledge and experience relevant to the buying and selling system of the seller before entering the wholesale market, amounting to 5 people who had previously conducted FGDs, but the interview process carried out to confirm matters that had not answered in the FGD. Interviews took place on the 3rd to December 7, 2019; (4) Literature study and documents especially relating to the sale and purchase system as well as the provisions of Islamic economic law on the terms and order of halal and prohibited trading, this research conducted in Makassar City in traditional markets.

\section{RESULTS AND DISCUSSION}

\section{Concept and Base of Talaqqi Rukban and Ikhtikar}

Talaqqi Rukban is also called Talaqqi as-Sila, a term used in the Muamalah fiqh which explains the process of purchasing commodities/goods by intercepting villagers who carry commodity (crops: staple food, vegetables and fruits, and fish). Before entering the parent market and the seller does not yet know the real basic price in the market; the buyer immediately makes an offer, and after an agreement has made, then the buyer can obtain adequate profits (Asyari, 2003).

Ihtikar or known in the Indonesian language as the hoarding of the commodity is one of the economic problems that are serious enough not to mention Islam, which has normatively predicted it, but also non-Islam (Hakim, 2016). In the case of food stockpiling, two things can understand. First, people who hoard food items to make it as a backup to face the food crisis and then sell it at a reasonable price; this is not a problem / not forbidden. Second, if the hoarding motivation is to wait for high costs in terms of wanting to get greater profits, then this is forbidden because the treatment is contrary to the benefits of the ummah, in connection with this the Ulema grants specific criteria in the prohibited Ihtikar.

To avoid the occurrence of Ihtikar, one way that must take is to prevent monopolistic practices in the management of commodities. Such methods must restrict to avoid a large madlarat for the community. This action is following the principle of Saduz-zari'ah in Islam. To realize this, the role of the government is 


\section{Jurnal Ilmiah Al-Syir'ah Vol. 18, No. 1 (2020): 50-62 \\ Website: http://journal.iain-manado.ac.id/index.php/JIS \\ ISSN 2528-0368 (online) ISSN 1693-4202 (print)}

enormous considering that it has power (authority). With his administration, he has the right to regulate and prevent the practice of Ihtikar and monopoly. So that the benefits of the ummah can be protected, however, in preserving the profits of the ummah, the maslahah far dliyyah (individually) must not be prioritized. One of the evidence for the legalization of government interventions in controlling the market is the traditions of the Prophet, the actions of Umar Ibn Khattab, and Usman Ibn 'Affan (Hakim, 2016).

Goods that stockpiled should go through a process of a prior purchase from the community. Meanwhile, if the commodities are solely from the results of planting itself, the prohibited ikhtikar in the form of goods is in the way of staple food (qut), and the hoarding of merchandise should make it difficult for the community. Among those that indicate this is if, in one city, there was only one muhtakir (sustaining mastery of commodities).

The avoid of ihtikar, one of the ways that must take is to prevent monopolistic practices in the management of commodities to avoid enormous harm to the community; this action is following saaduz-zaraiyyah in Islamic jurisprudence. Thus the role of government in carrying out market supervision is very determining the law in the form of ta'zir, so that policies can run in law enforcement, thus the role of government is crucial and needed so that public benefit can be protected (Wahyuni, 2010).

Both of these practices are trading practices that prohibited in Islam, both of them are detrimental to the community, especially the society, by being disregarded and have less purchasing power, both of these practices can also intertwin at certain times. Like the perpetrators of Talaqqi Rukban, who stopped the sellers of their agricultural products that had not yet arrived at the market by buying up their merchandise at meager prices, then stockpiling the goods so that the market was scarce that this person automatically became the head of ihtikar. Furthermore, sell these items at very high prices. Even though the practice of Talaqqi Rukban and Ihtikar is not always the same perpetrator, there can be a collaboration between these people.

Talaqqi Rukban is not always related to Ihtikar's practice and vice versa. Some only method Talaqqi Rukban and only those who practice Ihtikar. But both of these practices are very despicable because they harm many people. It is not only the low-income people who have affected but also the middle and upper-class communities who are also affected. Although for the upper-middle-class people are not felt because the income is entirely even above average.

This Talaqqi Rukban is following the Word of Allah SWT, QS. An-Nisa: 29 "O you who believe! Do not eat one another falsely's the property, except in the way of trade that applies with equal affection among you. And don't kamun kill yourself; surely Allah is Most Merciful to you; and QS. Al-Maidah: 2 "And please help you in doing good and pious and do not help in committing sins and transgressions." 


\section{Jurnal Ilmiah Al-Syir'ah Vol. 18, No. 1 (2020): 50-62 \\ Website: http://journal.iain-manado.ac.id/index.php/JIS \\ ISSN 2528-0368 (online) ISSN 1693-4202 (print)}

Also, the Hadith, which was handed down by Abdullah bin Abbas (may Allah be pleased with him), said, The Prophet (s) once said: do not pick up / welcome trade caravans and do not city people buy merchandise from villagers. Then asked Ibn Abbas what meant not to buy goods from villagers? Ibn Abbas said in buying and selling, and there is no simsar (Nahdliyah, 2010). In another narration also told from Abdullah bin Maslamah bin Bilal, from Yahya bin Sa'id said, Sa'id bin Musyayyab said that verily ma'mar said; The Messenger of Allah has said: Anyone who practices Ihtikar (monopoly) then he is a sinner. Then it was told to Sa'id, then verily you have done Ihtikar, Sa'id said; In fact, the ma'mar who narrated this Hadith also did Ihtikar (HR. Muslim) (Ginting, 2016).

Furthermore, it can understand that there are six forms of banned buying and selling, namely: (1) Selling above the sale of his brother as the Hadith, which means: Do not sell anything above the sale of his brother. There should not be a sermon (Applying) above the Brother's Sermon unless there is permission for it (Kumalasari \& Na'imah, 2017); (2) Buying and selling Najezy is: let no one sell above the sale of his brother. city people who become brokers to sell villagers' goods (Isro, 2017); (3) Talaqqil Jalab / Rukban; (4) Buying and selling lil balad (Becoming Scalpers for villagers) (Machmudah, 2009); (5) Buying and selling in the form of stockpiling goods (Ikhtikar). Al Qadi Iyyad said the reason for this prohibition was to avoid everything that was troubling Muslims at large (AlQaradhawi \& Daud, 2016).

\section{Buy and Sell with Counterfeit Cash}

Describe items through pictures, audio, or writing and have high and attractive prices even though it is only a trick to trick the buyer. There are three Terms of Forbidden Sale, and Purchase, namely: (1) The goods offered for sale are goods issued by many people, both food and others; (2) Buying and selling recommended for the current price. While paid when paid, the problem was agreed; (3) The villager does not know the cost of the goods sold in the city, if he knows, the problem is recognized (Isnawati, 2019). The reason for the prohibition of buying and selling is related to the commitment to the contract, namely buying and selling containing usury and buying and selling carried out, providing fraud.

Prohibition of trade deals with hardship, in which it contains several elements: (1) The component of bid engineering for farmers who do not know market prices; (2) inventory of goods in the empty market; (3) lack of price information due to market dynamics; (4) monopolistic element, namely buying products that have a direct relationship with farmers producers, so that it influences the market mechanism and price formation due to the lack of market traders. As a result, people forced to fight over these items by increasing offers or forced to buy at that price because they need it (Thalib, 1999).

The principle which becomes the basis for selling is mubah except four things: (1) all forms of selling mubah except those which forbidden in the Qur'an and al-Hadith; (2) Muamalaqh is done based on consideration of bringing benefits

Talaqqi Rukban and Ihtikar in The Traditional Market at Makassar in Perspective of Islamic Economic Laws 


\section{Jurnal Ilmiah Al-Syir'ah Vol. 18, No. 1 (2020): 50-62 \\ Website: http://journal.iain-manado.ac.id/index.php/JIS \\ ISSN 2528-0368 (online) ISSN 1693-4202 (print)}

and eliminating mudharat (danger) in social life; (3) Muamalah done voluntarily without any compulsion; (4) Muamalah is carried out by maintaining the value of justice, avoiding the elements of persecution, the aspects of taking opportunities in narrowness (Basyir, 2014).

Sayyid Sabiq explained that the law of buying and selling could be: Haram, mubah, Sunnah and mandatory for the following conditions: (1) The rule of buying and selling becomes mandatory in an emergency and forced to be in dire need of food or drinks while he can do buying and selling ; (2) Buying and selling forbidden if selling trades that are prohibited by sharia such as selling pigs; (3) Buying and selling is Sunnah if a person swears to sell goods that are not harmful, then carrying out such is the Sunnah; (4) Buying and selling in law Makruh, if the transaction is carried out when finished the call to prayer Friday prayers, then still buying and selling (Sabiq, 2004).

Buying and selling are always legal if done based on like and like between the two. The principle of liking and like this states that: Every form of selling between an individual or between parties must be based on their willingness. Willingness can mean a desire to do muamalah forms, or willingness in the sense of accepting or surrendering assets that are used as objects of engagement and other types of selling (Praja, 1995). The Ulema agree that the sale and purchase and diligence have been justified since ancient times until now. However, in its development experienced some changes in the form or model of buying and selling that requires thought (ijtihad among scholars).

In Islamic Law, there are several types of buying and selling in terms of the law, according to jumhur ulama dividing in two, namely legal buying and selling. Sahih, namely buying and selling, which has fulfilled the terms and conditions as well as buying and selling, which is wicked, namely buying and selling that does not reach the terms and conditions (the pillars) (Apriliawati, 2017). The views of jumhur Ulama explain that there are four pillars of sale and purchase, namely those who have the intention (Seller and buyer), Sighat (lafatz consent and escape, There are goods purchased, and there is a replacement exchange rate of products (Usman, 2002).

The conditions for sellers and buyers are: (1) Mumayyiz and understanding are not crazy or still stupid, and understand good and bad deeds; (2) Like each other, do not influence each other between the two so that it does not cause an element of coercion in carrying out the sale and purchase agreement; (3) Must be a different person, meaning someone cannot act at the same time as a seller and buyer (Mujiatun, 2014). According to the Fikh experts, a condition of the person buying and selling not considered valid unless it not mentioned in the core of the contract. It does not find adequate a situation that is called before the contract or after the contract made (Fauzan, 2006).

The sale and purchase transaction shall only be declared to occur if the conditions of sale and purchase fulfilled as follows: (1) two parties are conducting 


\section{Jurnal Ilmiah Al-Syir'ah Vol. 18, No. 1 (2020): 50-62 \\ Website: http://journal.iain-manado.ac.id/index.php/JIS ISSN 2528-0368 (online) ISSN 1693-4202 (print)}

the sale and purchase transaction; (2) There is something that transferred from the seller to the buyer; (3) There is a sentence stating the sale and purchase transaction (Sighat and qabul) (Kamal \& Dkk, 2002).

\section{Overview of Traditional Markets and Practices of Talaqqi Rukban and Ihtikar at Makassar}

The city of Makassar geographically located at position 119.24 '17 '38 east longitude - 58 '6 '19 "south latitude. It covers an area of around $175.77 \mathrm{~km}$, has fifteen subdistricts - the city located in the western part of South Sulawesi Province with borders. Maros Regency northside (Biringkanaya sub-district), Southside (Tamalate sub-district) bordered by Gowa, East Side (Biringkanaya District in Manggala. Maros border it in the West (Tallo District), bordered by the Makassar strait.

Table 1, have divided the District, Sub-districts, and Markets, where there are several markets in the City of Makassar that often occur in Talaqqi Rukban and Ihtikar practices. Makassar is the capital of South Sulawesi recorded in history as one of the trade centers in the eastern part of Indonesia. Because of its geographical location and is the site of the flow of traffic, Even Southeast Asia, with a seaport known as the Port of Sukarno Hatta and Sultan Hasanuddin airport. Likewise, it is known as a stopover center for traders who come from eastern Indonesia and the western part.

Makassar city government formed PD. Makassar Raya Market based on Regional Regulation number 4 of 1999, which follows up with the issuance of the Makassar mayor decree number: 8175 in 1999. December 11, 1999. The Makassar Raya Market, besides, is expected to formulate a strategy formula for obtaining funds in managing, managing, and constructing infrastructure facilities/infrastructure. It also expected to be able to finance itself while bringing profits to the city government in the form of revenue from Regional Original Income. Furthermore, it also demanded to change the public image of a dirty, dirty, and chaotic market into a safe, neat, and clean market.

The practice of Talaqqi Rukban and Ihtikar in Makassar is still very massive. Even this practice usually occurs around the mosque, where the mosque is often a stopover for prayer and other religious activities. The author highlights the person who is a principal Talaqqi Rukban and Ihtikar are religious people and commonly called the community as the Hajj (call people who have performed the pilgrimage). These persons certainly know the types of buying and selling that prohibited in Islam.

In table 1, you can see the names of the Districts, Sub-Districts, and Markets as follows: 
Jurnal Ilmiah Al-Syir'ah Vol. 18, No. 1 (2020): 50-62

Website: http://journal.iain-manado.ac.id/index.php/JIS ISSN 2528-0368 (online) ISSN 1693-4202 (print)

Table 1. District, Sub-Districts, and Market Names in Makassar

\begin{tabular}{|c|c|c|c|}
\hline No. & Name of District & Name of Sub-Districts & Name of Market \\
\hline 1 & Biringkanaya & $\begin{array}{l}\text { Bulu Rokeng; Daya; Paccarakkang; } \\
\text { Pai; Sudiang; Sudiang Raya; Untia; } \\
\text { Berua, Bakung, Laikang. }\end{array}$ & Pasar Daya \\
\hline 2 & Bontoala & $\begin{array}{l}\text { Baraya; Bontoala; Bontoala Parang; } \\
\text { Bontoala Tua; Bunga Ejaya; Gaddong; } \\
\text { Layang; Malimongan Baru; Parang } \\
\text { Layang; Timungan Lompoa; Tompo } \\
\text { Balang; Wajo Baru. }\end{array}$ & $\begin{array}{l}\text { Pasar Terong; } \\
\text { Pasar Kalimbu; } \\
\text { Pasar Pannampu; } \\
\text { Pasar Cidu }\end{array}$ \\
\hline 3 & Makassar & $\begin{array}{l}\text { Bara Baraya; Bara Baraya Selatan; } \\
\text { Bara Baraya Timur; Bara Baraya } \\
\text { Utara; Barana; Lariang Bangi; } \\
\text { Maccini; Maccini Gusung; Maccini } \\
\text { Parang; Maradekayya; Maradekayya } \\
\text { Selatan; Maricayya; Maricayya Baru. }\end{array}$ & Pasar Maricayya \\
\hline 4 & Mamajang & $\begin{array}{l}\text { Baji Mappakasunggu; Bonto Biraeng; } \\
\text { Bonto Lebang; Karang Anyar; } \\
\text { Labuang Baji; Mamajang Dalam; } \\
\text { Mamajang Luar; Mandala; Maricayya } \\
\text { Selatan; Pa'batang; Parang; Sambung } \\
\text { Jawa; Tamparang Keke. }\end{array}$ & Pasar Sambung Jawa \\
\hline 5 & Manggala & $\begin{array}{l}\text { Antang, Bangkala, Batua, Borong, } \\
\text { Manggala, Tamangapa, Biring } \\
\text { Romang, Bitowa. }\end{array}$ & $\begin{array}{l}\text { Pasar Antang; } \\
\text { Pasar Jongkok }\end{array}$ \\
\hline 6 & Mariso & $\begin{array}{l}\text { Bontorannu; Kampung Buyang; } \\
\text { Kunjung Mae; lette; Mario; Mariso; } \\
\text { Mattoanging; Panambungan; } \\
\text { Tamarunang. }\end{array}$ & \\
\hline 7 & Panakukang & $\begin{array}{l}\text { Karampuang; Karuwisi; Karuwisi } \\
\text { Utara; Masale; Pampang; Panaikang; } \\
\text { Pandang; Paropo; Sinrijala; } \\
\text { Tamamaung; Tello Baru. }\end{array}$ & Pasar Tamaumau \\
\hline 8 & Rappocini & $\begin{array}{l}\text { Balla Parang; Banta Bantaeng; Minasa } \\
\text { Upa; Bua Kana; Gunung Sari; } \\
\text { Karunrung; Kassi Kassi; Mappala; } \\
\text { Rappocini; Tidung. }\end{array}$ & $\begin{array}{l}\text { Pasar Kassi Kassi; } \\
\text { Pasar Tamalate }\end{array}$ \\
\hline 9 & Tallo & $\begin{array}{l}\text { Bunga Ejaya; Kalukuang; Kaluku } \\
\text { Bodoa; La'Latang; Lakkang; Lembo; } \\
\text { Pannampu; Rappojawa; Rappokalling; } \\
\text { Suangga; Tallo; Tammua; Ujung } \\
\text { Pandang Baru;Wala Walayya; Buloa. }\end{array}$ & \\
\hline 10 & Tamalanrea & $\begin{array}{l}\text { Bira; Kapasa; Kapasa Raya; Parang } \\
\text { Loe; Tamalanrea; Tamalanrea Indah; } \\
\text { Tamalanrea Jasa; Buntusu;Katimbang. }\end{array}$ & Pasar Kapasa \\
\hline 11 & Tamalate & $\begin{array}{l}\text { Balang Baru; Barombong; Bongaya; } \\
\text { Jongaya; Maccini Sombala; Mangasa; } \\
\text { Manuruki; Pa'Baeng Baeng; Parang } \\
\text { Tambung; Tanjung Merdeka; Bonto } \\
\text { Makkio; Bonto Duri. }\end{array}$ & $\begin{array}{l}\text { Pasar Pa'baeng } \\
\text { Baeng }\end{array}$ \\
\hline 12 & $\begin{array}{l}\text { Ujung Pandang } \\
\text { Baru }\end{array}$ & $\begin{array}{l}\text { Bulo Gading; Lae Lae; Lajangiru; } \\
\text { Losari; Maloku; Mangkura; Pisang } \\
\text { Selatan; Pisang Utara; Sawerigading. }\end{array}$ & \\
\hline 13 & Ujung Tanah & $\begin{array}{l}\text { Camba Berua; Cambaya; Gusung; } \\
\text { Pattingaloang; Pattingaloang Baru; }\end{array}$ & \\
\hline
\end{tabular}


Jurnal Ilmiah Al-Syir'ah Vol. 18, No. 1 (2020): 50-62

Website: http://journal.iain-manado.ac.id/index.php/JIS

ISSN 2528-0368 (online) ISSN 1693-4202 (print)

\begin{tabular}{lll}
\hline & Tabaringang; Tamalabba; Totaka; \\
& Ujung Tanah. \\
& & Pulau Barang Lompo; Pulau Lumu \\
& Lumu; Pulau Barang Caddi; Pulau \\
& Kodingareng; Langkai; Lanjukang \\
& Sangkarrang & Butung; Ende; Malimongan; \\
& Malimongan Tua; Mampu; Melayu; \\
& Melayu Baru; Pattunuang \\
\hline
\end{tabular}

Source : Data From PD. Pasar Makassar Raya Kota Makassar 2019.

Traditional markets are markets that play an essential role in advancing economic growth in Indonesia and have a natural competitive advantage. Its existence is beneficial, not only for the regional or central government but also for the people who depend on their lives in trading activities. Because, in traditional markets, many actors have significance and try to prosper their experiences, both traders, buyers of pelvic workers, and so on.

The development of globalization, the rate of socio-economic conditions of society, and changes in the value system have brought about change-changes in life patterns and community needs. To meet the desires and needs of the community, various shopping facilities have emerged and have become an essential place in people's lives. For the city, the market is not just a place where sellers and buyers meet traditional values. Traditional markets are places where sellers and buyers trade, generally in the form of stalls, booths, open platforms with tents and halls.

The Islamic economic principles aim to develop the wisdom of all parties, as stated in the concept of Falah contained in the Qur'an. This principle connects economic principles with direct moral values. The achievement of Falah, economic activity must include moral foundations. In making decisions relating to economics, ethical values should use as the norm, and subsequently relating to economics must be considered an honest relationship (Muhammad, 1996).

Furthermore, Yusuf Qardawi (1997) explains among the Syar'iat norms or values that are as follows: (1) Enforce the prohibition of trading prohibited goods. Commodities traded are good and halal goods. Allah commands to consume and produce and distribute and sell halal and excellent products, as explained in Surah QS. al-Baqarah: 168; (2) Be honest and trustworthy.

The intended behavior is the spirit of the faith, the main characteristic of believers, and even the Prophets. Without truth, religion will not be upright and unstable; on the contrary, lies, and lies are part of a hypocritical nature. The biggest catastrophe on the market today is rampant lies and sleaze. One of the hadiths of the Prophet Muhammad SAW, which means "honest and trusted business people join the prophets, the righteous and the martyrs on the Day of Judgment" (HR. AtTirmidzi) (Darussalam, 2019). 
Jurnal Ilmiah Al-Syir'ah Vol. 18, No. 1 (2020): 50-62

Website: http://journal.iain-manado.ac.id/index.php/JIS

ISSN 2528-0368 (online) ISSN 1693-4202 (print)

This behavior does not make gharar ba'iat (buying and selling that does not contain obscurity). Do not deal with usury institutions. Thus are some explanations on prohibited trading elements as well as some harmonious guidelines and terms of sale agreed upon by the ulama jumhur in their halal and prohibited conditions.

\section{CONCLUSION}

Opinions from the scholars and facts that occur in Makassar City are related to the practice of Talaqqi Rukban and Ihtikar. The author can conclude that the application of buying and selling in Makassar City is partly not following Islamic Economic Law. Many factors make the writer complete this, namely in terms of honesty in buying and selling transactions. Religious norms violated by practitioners of Talaqqi Rukban and Ihtikar practices. No proof justifies this practice; even the scholars agree to forbid and denounce the perpetrators who practice Talaqqi Rukban and Ihtikar.

\section{ACKNOWLEDGMENT}

The writer, thanks to rector Universitas Hasanuddin Makassar and also thanks all the editorial teams of the Jurnal Ilmiah Al-Syir'ah who helped publish this article.

\section{REFERENCES}

Al-Qaradhawi, Y., \& Daud, M. H. bin. (2016). Halal dan Haram dalam Islam. Publishing House Sdn. Bhd.

Apriliawati, D. (2017). Perspektif al-Madhahib al-Arba'ah terhadap jual beli biji Genitri di Desa Soso Kecamatan Gandusari Kabupaten Blitar. Surabaya: UIN Sunan Ampel Surabaya.

Asyari. (2003). Kamus Istilah Ekonomi Syari'ah. Al-Ma'arif.

Basyir, A. A. (2014). Asas-asas Hukum Muamalah. Yogyakarta: UII Press.

Darussalam, A. (2019). Paradigma Bisnis Islam Perspektif Hadis. Tahdis: Jurnal Kajian Ilmu Al-Hadis, 6(1).

Daymon, C., \& Holloway, I. (2008). Metode-metode riset kualitatif dalam public relations dan marketing communications. Bentang Pustaka.

Fauzan, S. A. (2006). Fikhi Sehari-Hari. Gema Insani.

Ginting, E. D. (2016). Monopoli dalam Islam. Jurnal Ilmiah Penegakan Hukum, $3(1), 50-59$.

Hakim, L. (2016). Ihtikar Dan Permasalahannya Dalam Perspektif Hukum Islam. Jurnal Darussalam: Jurnal Pendidikan, Komunikasi Dan Pemikiran Hukum Islam, 7(2), 320-330.

Himawan, A. (2011). Tinjauan Ekonomi Islam terhadap Transaksi Finansial di Pasar Modal Indonesia. Jakarta: UIN Syarif Hidayatullah.

Talaqqi Rukban and Ihtikar in The Traditional Market at Makassar in Perspective of Islamic Economic Laws 


\section{Jurnal Ilmiah Al-Syir'ah Vol. 18, No. 1 (2020): 50-62 \\ Website: http://journal.iain-manado.ac.id/index.php/JIS \\ ISSN 2528-0368 (online) ISSN 1693-4202 (print)}

Isnawati, L. (2019). Jual Beli Online Sesuai Syariah. Lentera Islam.

Isro, M. (2017). Makelar Mobil dalam Perspektif Hukum Islam (Studi di Showroom Sultan Haji Motor Kelurahan Sepang Jaya Kecamatan Kedaton Bandar Lampung). Lampung: UIN Raden Intan Lampung.

Kamal, M., \& Dkk. (2002). Fikih Islam Sesuai Dengan Putusan Majelis Tarjih. In Citra Karsa Mandiri, Yogyakarta. Yogyakarta: Citra Kersa Mandiri.

Kumalasari, A., \& Na'imah, E. (2017). Hadis tentang Larangan Menjual Barang Yang Tidak Dimiliki (Kajian Hadis Tematik). Surakarta: IAIN Surakarta.

Machmudah, M. (2009). Perspektif Hukum Islam dan UU No. 8 Tahun 1999 tentang Perlindungan Konsumen terhadap Jual Beli Udang Windu Gelonggong di Kelurahan Kalianyar Kecamatan Bangil Kabupaten Pasuruan. UIN Sunan Ampel Surabaya.

Mankiw, N. G. (2013). Macroeconimics (8 ed.). New York USA: Charles Linsmeier.

Marukum, S. B. B. (2012). Pemikiran Yusuf Al-Qardhawi tentang Ihtikar (Dalam Kitab Halal Haram Fil Islam). Riau: UIN Sultan Syarif Kasim Riau.

Mentari, S. (2015). Fenomena Talaqqi Rukban dalam Jual Beli di Desa Jambo Labu Kecamatan Birem Bayeun Kabupaten Aceh Timur. Langsa: IAIN Langsa.

Muhammad, N. S. (1996). Kegiatan Ekonomi dalam Islam. In Alih bahasa Anas Sidiq Jakarta: Bumi Aksara. Bumi Aksara.

Mujiatun, S. (2014). Jual Beli dalam Perspektif Islam: Salam dan Istisna'. JRAB: Jurnal Riset Akuntansi \& Bisnis, 13(2).

Muslim, M. B. (2010). Ihtikâr dan Dampaknya Terhadap Dunia Ekonomi. Jurnal Studi Al-Qur'an, 6(1), 1-14.

Nahdliyah, L. (2010). Analisis Hukum Islam terhadap Transaksi Nyegget Degheng yang Berpengaruh pada Equilibrium Price (keseimbangan harga) di Pasar Ikan kec. Ketapang kab. Sampang. UIN Sunan Ampel Surabaya.

Praja, J. S. (1995). Filsafat Hukum Islam. Bandung: LPPM Universitas Bandung.

Putri, D. (2019). Dampak Ihtikar Terhadap Mekanisme Pasar dalam Perspektif Islam. Imara: JURNAL RISET EKONOMI ISLAM, 3(2), 183-191.

Qardawi, Y. (1997). Norma dan etika Ekonomi Islam. Gema Insani.

Sabiq, S. (2004). Figh Sunnah Pengantar Imam Hasan Al-Banna, Jilid 3. Jakarta: Darul Fath.

Thalib, M. (1999). Bimbingan Bisnis dan Pemasaran Islami. Gema Risalah Press.

Ulfah, A. F. (2010). Kriteria komoditas Barang Dagangan yang Dilarang di Ihtikar Menurut Imam Al-Ghazali. Riau: UIN Sultan Syarif Kasim Riau.

Usman, M. (2002). Kaidah-Kaidah Ushuliyah \& Fiqhiyah. Jakarta: RajaGrafindo

Talaqqi Rukban and Ihtikar in The Traditional Market at Makassar in Perspective of Islamic Economic Laws 
Jurnal Ilmiah Al-Syir'ah Vol. 18, No. 1 (2020): 50-62

Website: http://journal.iain-manado.ac.id/index.php/JIS

ISSN 2528-0368 (online) ISSN 1693-4202 (print)

Persada.

Wahyuni, A. (2010). Penimbunan barang dalam perspektif hukum Islam. AlIqtishad: Jurnal Ilmu Ekonomi Syariah, 2(2). 